\title{
Spectrophotometric determination of phenol in the presence of congeners by multivariated calibration
}

\author{
KELY VIVIANE DE SOUZA and PATRICIO PERALTA-ZAMORA \\ Laboratório de Química Ambiental e de Materiais, Departamento de Química-UFPR \\ CP 19081, 81531-990, Curitiba-PR \\ Manuscript received on December 15, 2000; accepted for publication on August 9, 2001; \\ presented by Fer nando Gal embeck
}

\begin{abstract}
The generation of poly-hydroxilated transient species during the photochemical treatment of phenol usually impedes the spectrophotmetric monitoring of its degradation process. Frequently, the appearance of compounds such as pyrocatechol, hydroquinone and benzoquinone produces serious spectral interference, which hinder the use of the classical univariate calibration process. In this work, the use of multivariate calibration is proposed to permit the spectrophotometric determination of phenol in the presence of these intermediates. Using 20 synthetic mixtures containing phenol and the interferents, a calibration model was developed by using a partial least square regression process (PLSR) and processing the absorbance signal between 180 and $300 \mathrm{~nm}$. The model was validated by using 3 synthetic mixtures. In this operation, typical errors lower than $3 \%$ were observed. Close correlation between the results obtained by liquid chromatography and the proposed method was also observed.
\end{abstract}

Key words: Phenol, spectrophotometric determination, multivariated calibration.

\section{INTRODUCTION}

Multivariate calibration processes are very useful in analytical chemistry, mainly in the analysis of samples composed by several components that need individual determination from instrumental data with low selectivity (Miller 1995).

In view of characteristic such us: high sensibility, operational facility and low cost, the UV-VIS spectrophotometry could be one of the most useful analytical tools. Unfortunately, its chronic problems related to low selectivity usually impede the determination of analyses from complex matrixes.

The spectrophotometric determination of phenol in the presence of congeners is a very complex

Correspondence to: Patricio Peralta-Zamora

E-mail: zamora@quimica.ufpr.br

Fax: 41.3613186 problem in analytical chemistry due to the spectral interferences, which results in widely overlapped absorption bands. For this determination, the conventional univariate calibration method is impracticable, because of the contribution of one specie on the absorption signals of others, and vice versa.

The spectrophotometric resolution of mixtures of components with partially overlapped spectra has been the subject of numerous chemometric studies. Several mathematical models can be applied to the analytical data to obtain the model parameters, and then apply this model to estimate the analyse concentration in the samples. Among those, linear regression, partial least squares regression and principal components regression, have been used with success in complex determinations (Bautista et al. 1996a, Bautista et al. 1996b, Berzas Nevado et 
al. 1997).

This paper describes an analytical methodology for determination of phenol in the presence of typical products of its photochemical degradation by using a spectrophotometric method and a multivariate calibration technique (Partial Least-Squares Regression, PLSR). Multivariate calibration consists of the establishment of an association between matrixes of chemical data (Peralta-Zamora et al. 1997, 1998). The process is composed of two steps: calibration and prediction. In this case, the calibration step consists of the development of a mathematical model which can reproduce a concentration matrix Y (contains " $\mathbf{n}$ " lines which correspond to samples and ' $q$ " columns of different phenol concentrations) from a matrix $\mathbf{X}$ (with " $\mathbf{n}$ "' lines of samples and " $\mathbf{p}$ " columns of selected wavelength values).

\section{EXPERIMENTAL}

\subsection{React ant s and St andard Solutions}

Phenol, pyrocatechol, hydroquinone and benzoquinone were of analytical grade. Standard solutions were prepared in deionized water in concentrations of $1.0 \mathrm{molL}^{-1}$.

\subsection{In st rument at ion}

Spectrophotometric measurements were made with a HP 8154 A spectrophotometer, using $1 \mathrm{~cm}$ quartz cells. Chromatographic determinations were carried in a Waters equipment, using a C18 column, a methanol:water $(30: 70 \mathrm{v} / \mathrm{v})$ mobile phase and a spectrophotometric detector $(252 \mathrm{~nm})$.

\subsection{Photochemical Process}

The photochemical treatment was carried out in a $150 \mathrm{~mL}$ glass reactor, equipped with water refrigeration, magnetic stirrer and oxygenation system. Suspensions formed by $100 \mathrm{~mL}$ of phenol aqueous samples $\left(1 \times 10^{-3} \mathrm{molL}^{-1}\right)$ and $15 \mathrm{mg}$ of photocatalyst $(\mathrm{ZnO})$ were irradiated from the top with a 125 $\mathrm{W}$ medium pressure mercury lamp without the glass cover (fluence rate: $15 \mathrm{Jm}^{-2} \mathrm{~s}^{-1}$ at $\lambda>254 \mathrm{~nm}$ ), located at a distance of $12 \mathrm{~cm}$ from the solution sur- face. The system was bubbling with commercial oxygen at flows of about $10 \mathrm{mLmin}^{-1}$, through a sintered glass placed in the bottom of the reactor. For analytical control, samples were taken at convenient times and filtered through a $0.45 \mu \mathrm{m}$ Millipore filter.

\subsection{Analyt ical Procedure}

Known amounts of the standard solutions were placed in a $10 \mathrm{~mL}$ volumetric flask and completed to the final volume with deionized water. The final concentration of these solutions varied between $2.5 \times 10^{-7}$ and $2.5 \times 10^{-4}$ molL $^{-1}$ of each compound. This concentration range was selected since preliminary chromatographic studies showed that the concentration of the studied species reach this concentration interval, when a $1 \times 10^{-3} \mathrm{molL}^{-1}$ phenol solution is submitted to photochemical degradation at our experimental condition.

The absorption spectra were taken in the 180$300 \mathrm{~nm}$ range.

The Calibration was made with the conventional univariate method and a partial least-squares regression (PLSR), using the recorded adsorbance values between 180 and $300 \mathrm{~nm}$ as the dependent variables, with intervals of $2 \mathrm{~nm}$. The preprocessing program was developed in MATLAB 4.0 and the PLSR was performed by using the PLS-toolbox 1.5.

\section{RESULTS AND DISCUSSION}

The serious spectral interference between phenol and the typical transient species can be visualized from Figure 1. It is easy to observe from this figure that, even in the absence of phenol, the absorbance signal will be different of zero in the presence of any intermediary of the photochemical degradation process. It is clear that in this condition the univariate model induce to prevision errors that tend to infinite.

When a calibration set composed by 20 synthetic mixtures was submitted to the PLSR process, we observe that a conjunct of 4 principal components it is necessary to explain a great part of the variance of the analytical data. By using $4 \mathrm{CP}$ on 


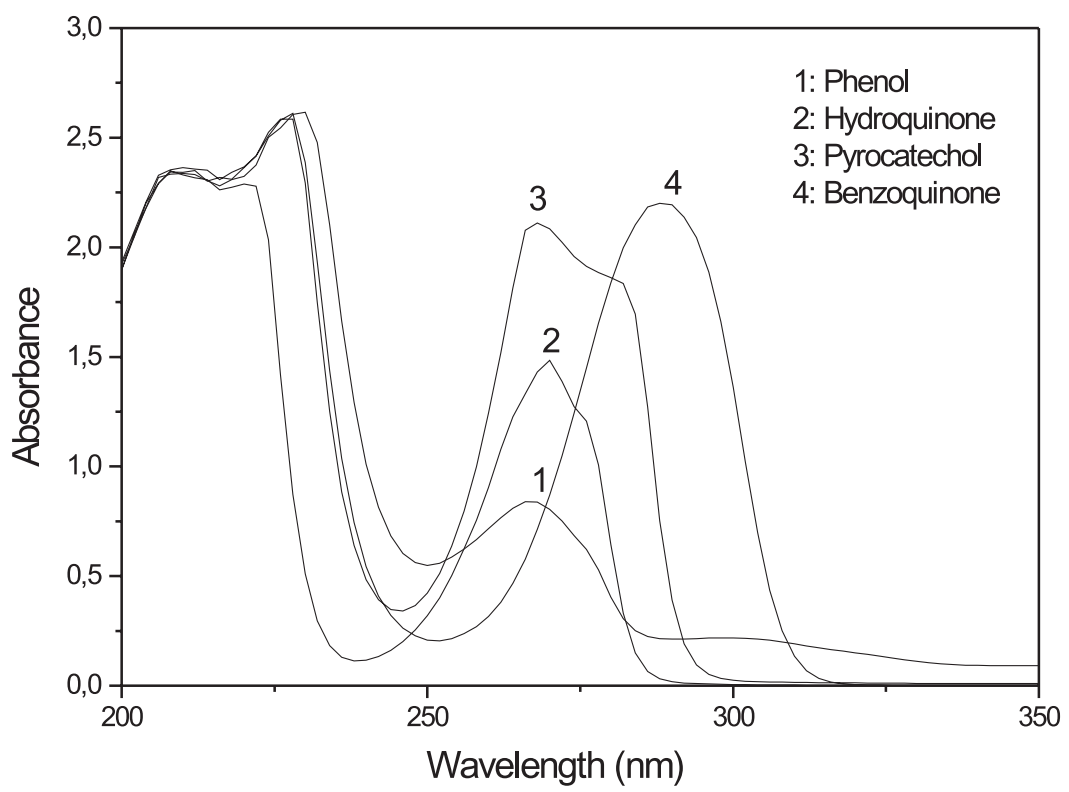

Fig. 1 - Typical UV-VIS spectra of phenol and congeners.

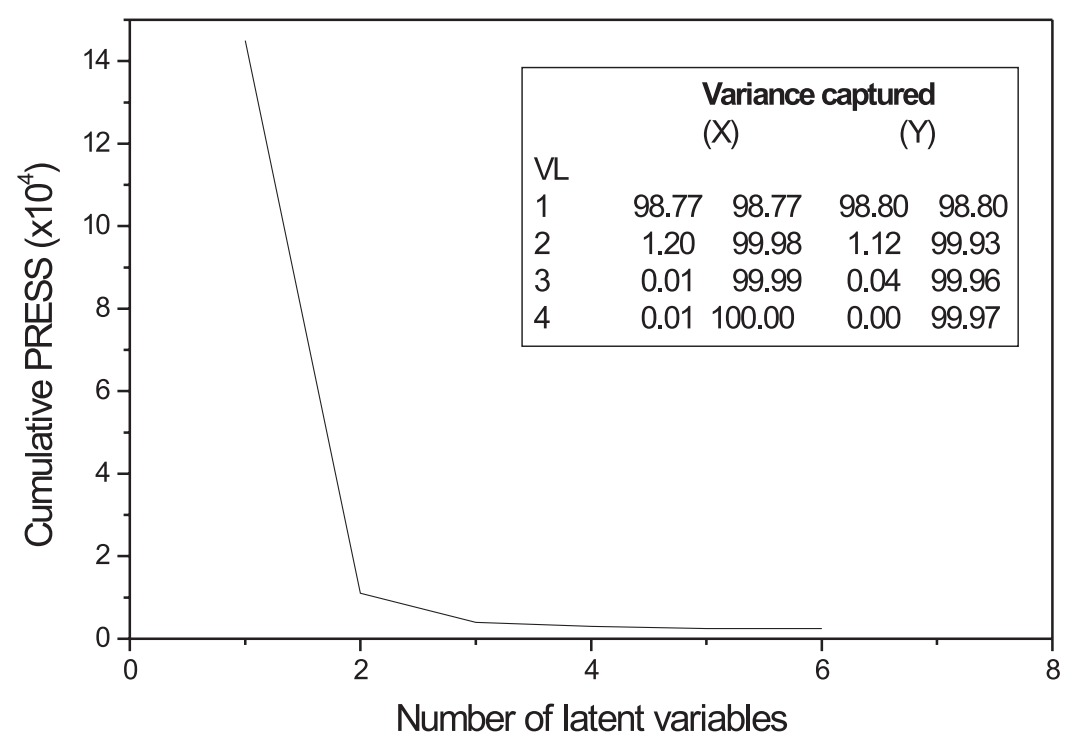

Fig. 2 - Cumulative PRESS as a function of the number of principal components. 
the model construction, a lower prediction error (PRESS) was observed (Figure 2). The great ability of the developed model to predict the concentration of the sampled used in the calibration stage can be visualized from Table I. In this stage, prevision errors lower than $6 \%$ were observed.

\section{TABLE I}

Predicted concentration of phenol for the calibration set.

\begin{tabular}{c|c|c}
\hline Sample & $\begin{array}{c}\text { Added } \\
\text { concentration } \\
\left(\mathrm{molL}^{-1}, \times 10^{4}\right)\end{array}$ & $\begin{array}{c}\text { Predicted } \\
\text { concentration } \\
\left(\mathrm{molL}^{-1}, \times 10^{4}\right)\end{array}$ \\
\hline 1 & 7.5 & 7.510 \\
2 & 5.0 & 4.969 \\
3 & 2.5 & 2.496 \\
4 & 0.5 & 0.530 \\
5 & 7.5 & 7.497 \\
6 & 5.0 & 4.976 \\
7 & 2.5 & 2.520 \\
8 & 0.5 & 0.491 \\
9 & 7.5 & 7.556 \\
10 & 5.0 & 4.973 \\
11 & 2.5 & 2.404 \\
12 & 0.5 & 0.482 \\
13 & 7.5 & 7.442 \\
14 & 5.0 & 5.033 \\
15 & 2.5 & 2.569 \\
16 & 0.5 & 0.465 \\
17 & 7.5 & 7.493 \\
18 & 5.0 & 5.035 \\
19 & 2.5 & 2.532 \\
20 & 0.5 & 0.525 \\
\hline
\end{tabular}

The robustness of the multivariate model was evaluated by predicting the phenol concentration in 3 different synthetic mixtures. The result (Table II) indicated that the model permits the resolution of this complex mixture, permitting prevision errors lower than $3 \%$.

Finally, the efficiency of the multivariate calibration model was appraised by monitoring the residual concentration of phenol during a photo-

\section{TABLE II}

Errors in the prediction of new samples.

\begin{tabular}{c|c|c|c}
\hline \multirow{2}{*}{ Sample } & \multicolumn{2}{|c|}{$\begin{array}{c}\text { Phenol concentration, } \\
\text { molL }^{-1}\end{array}$} & \multirow{2}{*}{ Error, \% } \\
\cline { 2 - 3 } & Predicted & Added & \\
\hline 1 & $6.05 \times 10^{-4}$ & $6.00 \times 10^{-4}$ & +0.8 \\
2 & $3.49 \times 10^{-4}$ & $3.50 \times 10^{-4}$ & -0.2 \\
3 & $7.73 \times 10^{-5}$ & $7.50 \times 10^{-5}$ & +3.0 \\
\hline
\end{tabular}

chemical degradation process, and comparing these results with those obtained by application of liquid chromatography and classical univariate spectrophotometry. The results (Figure 3) indicated a close correlation between the result obtained by chromatography and the proposed multivariate methodology. On the contrary, the results of the univariate calibration procedure show high positive errors, due to the presence of chemical species that absorb strongly in the monitored spectral region.

\section{FINAL REMARKS}

The information contained in a spectral data can be adequately expressed by using a conjunct of few principal components, which facilitates the elaboration of multivariate calibration models. The use of all the information registered by the instrument permit overcome the serious spectral interference usually observed in UV-VIS spectrophotometric methodologies, fact that increases its analytical potentiality and permit the analysis of complex samples.

\section{RESUMO}

A geração de espécies transientes polihidroxiladas, durante o tratamento fotoquímico de fenol, geralmente impede a utilização de espectrofotometria UV-VIS no monitoramento do processo de degradação. Freqüentemente, o surgimento de espécies como pirocatecol, hidroquinona e benzoquinona produz sérios problemas de interferências espectral, os quais inviabilizam a utilização de processos clássico de calibração univariada. Neste trabalho 


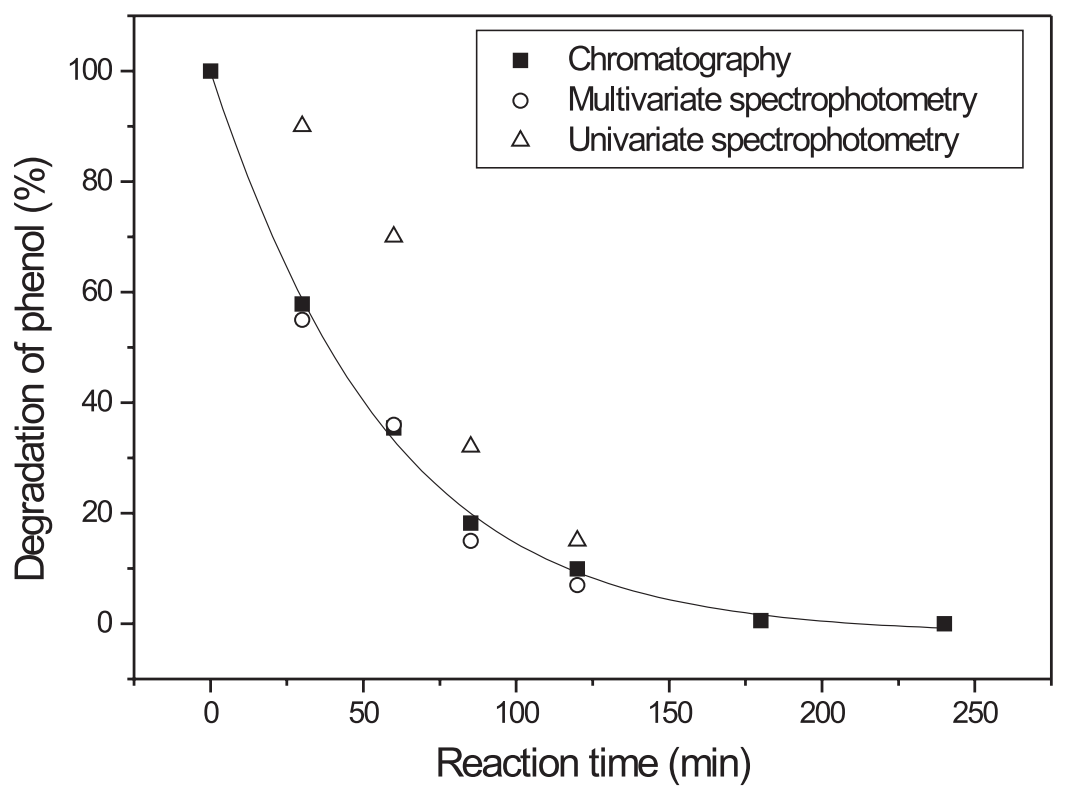

Fig. 3 - Photochemical degradation of phenol monitored by liquid chromatography and univariate and mulivariate spectrophotometry.

esta se propondo a utilização de processos de calibração multivariada para viabilizar a determinação espectrofotométrica de fenol na presença destes intermediários. O modelo de calibração multivariada foi desenvolvido por regressão de mínimos quadrados parciais (PLSR), utilizando-se 20 misturas sintéticas contendo fenol e interferentes e processando-se o sinal de absorbância obtido entre 180 e $300 \mathrm{~nm}$. O modelo foi validado utilizando-se um conjunto de 3 misturas sintéticas, o que levou à obtenção de erros de previsão típicos inferiores a 3\%. Uma excelente correlação foi também observada entre os resultados obtidos por cromatografia líquida e por aplicação do procedimento proposto.

Palavras-chave: Fenol, determinação espectrofotométrica, calibração multivariada.

\section{REFERENCES}

Baut ist a RD, Aberásturi FJ, Jiménez AI and Jimén ez F. 1996a. Simultaneous spectrophotomet- ric determination of drugs in pharmaceutical preparations using multiple linear regression and partial least-squares regression, calibration and prediction methods. Talanta, 43: 2107-2115.

Baut ist a RD, Jiménez AI, Jiménez F and Arias JJ. 1996b. Simultaneous spectrofluorimetric determination of europium, dysprosium, gadolinium and terbium using chemometric methods. Talanta, 43: 421-429.

Berzas Nevado JJ, Rodríguez Flores J and Castañeda Peñalvo G. 1997. Simultaneous spectrophotometric determination of ethinylestradiol and levonorgestrel by partial least squares and principal component regression multivariate calibration. Anal Chim Acta, 340: 257-265.

Miller CE. 1995. The use of chemometric techniques in process analytical method development and operation. Chemometrics and Intelligent Laboratory Systems, 30: 11-22.

Peralta-Zamora P, Cornejo Ponce L, Nagata 
N and Poppi RJ. 1997. Chemometric alternatives for resolution of classical analytical problems. Spectrophotometric determination of lanthanide mixtures. Talanta, 44: 1815-1822.
Peralta-Zamora P, Kunz A, Nagata N and Poppi RJ. 1998. Spectrophotometric determination of organic dye mixtures by using multivariate calibration. Talanta, 47: 77-84. 